\title{
EUROBOND UNDERWRITER SPREADS ${ }^{+}$
}

\author{
Neil Esho* \\ Michael G Kollo** \\ and \\ Ian G. Sharpe***
}

January 2004

\section{JEL Codes: G24, G15.}

Keywords: Underwriter spread, Eurobonds, Governing law.

\begin{abstract}
We examine the determinants of underwriter spreads on straight/fixed rate Eurobonds issued by U.S. firms between 1990 and 1998. We find that underwriter spreads are influenced by: (i) the governing law as it influences the timely and orderly renegotiation of contract terms, with bonds governed by English law having significantly lower spreads; (ii) the distribution mechanism, with spreads higher on public issues than private placements; (iii) underwriter reputation, with more reputable underwriters charging higher fees; and (iv) the choice of currency, with spreads higher in the less frequently utilized currencies and/or in currencies where underwriting activities are more concentrated.
\end{abstract}

Corresponding author: $\quad$ M. G. Kollo,

Financial Markets Group,

London School of Economics, London WC2A $2 \mathrm{AE}$.

Tel: $+44(0) 2078523574$

Fax: +44(0)2079557420

Email: m.g.kollo@lse.ac.uk

* Australian Prudential Regulatory Authority (APRA). The views and opinions in this paper are those of the author and do not necessarily reflect those of APRA.

** London School of Economics.

*** University of New South Wales.

${ }^{+}$The authors would like to thank Vince Hooper, Suk-Joong Kim, Gabriel Noti, Ronan Powell, LiAnne Woo, and participants at the $15^{\text {th }}$ Australasian Finance and Banking Conference 2002, the 2003 FMA Annual Meetings, and at research workshops at the University of Melbourne, University of Technology-Sydney, and the University of New South Wales for helpful comments on earlier drafts of the paper. The Australian Research Council assisted with financial support. 


\section{EUROBOND UNDERWRITER SPREADS}

The last decade has witnessed enormous growth in both volume and sophistication of the international financial markets, and particularly the Eurobond market. This growth has been facilitated by several factors including increasing globalisation, restrictive legal environments within domestic markets, illiquid domestic markets, high barriers of entry into domestic markets, and favourable financing opportunities (Giddy (1995, p. 129) and Kim and Stulz (1988)).

Despite the importance of the Eurobond market as an alternative source of funds for U.S. firms, and the role of underwriter spreads in the cost of those funds, there has been no prior study of the determinants of underwriter fees in that market. This is somewhat surprising as there is an extensive literature dealing with underwriter spreads in U.S. debt and equity markets. It has focused on clustering in IPO underwriter spreads at the 7\% level, the effects of certification and signaling of the quality of the issue by more reputable underwriters, the benefits of an ongoing underwriter/issuer relationship, the presence of risk based investor clienteles, scale economies in underwriter spreads, and the effect of Rule $144 \mathrm{~A}$ issues. ${ }^{1}$

The primary objective of our study is to extend the U.S. domestic debt and equity market literature on underwriter spreads to incorporate two factors that are unique to the international debt markets, the choice of governing law and currency of denomination. Eurobonds carry a choice of law clause that subjects the payment obligations of the borrower to one governing system of law. This provides a guide to the validity, enforceability, and interpretation of the contractual and other legal aspects of the Eurobond. In practice, the applicable legal systems most often used are the English and New York

\footnotetext{
${ }^{1}$ See Megginson and Weiss (1991), Roden and Bassler (1996), Altınkılıç and Hansen (2000), Jewell and Livingston (1998), Jain and Kini (1999), Livingston and Miller (2000), Chen and Ritter (2000), Hansen (2001), Roden and Mullineaux (2002)), and Livingston and Zhou (2002).
} 
laws. While these legal systems have many similarities, there are important differences that affect the ability to renegotiate contract terms in the event of default. Wood (1995, p. 179180) notes that New York law is more stringent in its protection of individual bondholder's rights and less amenable to private workouts. Consequently, a contract under English governing law may be viewed as having lower renegotiation risk than one under New York law. As the choice of governing law influences the risk of the investment, the potential investor base for the issue, and the marketing effort required by the underwriter, it is expected to influence the underwriter spread on the issue.

The currency of denomination is an important element of the Eurobond contract that sets it apart from domestic bonds. While Eurobonds may be denominated in any currency of choice, issuers have access to cross-currency swaps to mitigate foreign exchange exposure. ${ }^{2}$ Investors in Eurobonds denominated in currencies other than their home nation will either incur the costs of cross-currency hedging or be exposed to foreign exchange risk. When investors face higher risks in investing in an issue, underwriters may incur higher distribution costs and charge higher fees. Moreover, in some countries institutional investors are limited in their ability to invest in securities denominated in a foreign currency, enhancing the possibility of currency based investor clienteles (see Lanoo (1998, p. 318)). Thus an important aspect of this study is an examination of the effect of the choice of currency denomination on Eurobond underwriter spreads.

A secondary objective of our study is to examine whether several results relating to the determinants of underwriter spreads in U.S. debt and equity markets are also observed in the Eurobond market. The Eurobond market is less regulated than the U.S. domestic bond market while the market for Eurobond underwriting services is less concentrated than underwriting in the domestic bond market (see Smith and Walter (1997, pp 248-249 \& 270-

\footnotetext{
${ }^{2}$ Shapiro (1999, p.534) notes that it is estimated that $70 \%$ of Eurobond issues are swap driven.
} 
272)). Moreover, some countries have protected their domestic investment banking industry by imposing significant entry costs on foreign underwriting firms that may be reflected in higher underwriter fees (see Fisher (1988)).

Among the regulatory differences between the U.S. bond market and the Eurobond market are those relating to the method of distributing the bonds. Livingston and Zhou (2002) argue that Rule 144A private placements in the U.S. have offsetting influences on underwriter spreads. On the one hand, Rule 144A issues have less onerous disclosure requirements and are generally associated with greater information asymmetries (Carey et al (1993, p. 33)). This results in greater risk for investors and higher distribution costs for underwriters. On the other hand, private placements are generally sold to a small number of institutional investors and avoid the "road show" costs associated with public issues. Consequently, they involve lower marketing and distribution costs for the underwriter. Although the Rule 144A exemption is of less relevance for Eurobond issues, private placements of Eurobonds generally involve less disclosure than public issues which are usually listed and thus subject to disclosure rules of the relevant Exchanges. However, the information asymmetry normally associated with issuers of private placements in the U.S. domestic market is likely to be of lesser concern in Eurobond markets given the high credit quality and reputation of Eurobond issuers. Thus the choice between a private placement and public issue of Eurobonds is likely to be driven more by relative costs of the alternative distribution mechanisms than information asymmetries.

Finally, a study of underwriter spreads in the Eurobond market allows us to reexamine the role of underwriter reputation in setting spreads. Chemmanur and Fulghieri (1994) model the value of reputation to underwriters of initial public offers based on a dynamic trade-off between setting strict standards in evaluating firms that increases underwriter reputation, and setting lower standards that produce greater short-term revenue 
but at a cost to long-term reputation. They show that underwriters with better reputations charge higher fees than less prestigious rivals. ${ }^{3}$ However, empirical studies of underwriter spreads in U.S. debt and equity markets have found mixed results. The Megginson and Weiss (1991), Roden and Bassler (1996) and Livingston and Miller (2000) studies of underwriter spreads for initial public offers, municipal bonds, and non-convertible debt respectively have found an inverse relationship between underwriter reputation and underwriter fees ${ }^{4}$ while Beatty and Welch (1996) find a positive relationship for their sample of domestic equity offerings. Our study of Eurobond underwriter spreads provides further evidence on the relationship between underwriter fees and underwriter reputation.

To examine the effect of choice of governing law, distribution mechanism, underwriter reputation, and currency of denomination on underwriter spreads it is necessary to control for other influences such as the risk and size of the issue. The multivariate model incorporating these influences is specified in Section I of 
involves the issuer and lead underwriter negotiating a price and a "fixed" underwriting discount for the issue that is non-discountable by other underwriters of the issue.

The dependent variable, denoted 'Fee' and referred to as the underwriter spread, is the ratio of the gross fee charged by the underwriter to gross proceeds of the issue. It includes management fees, sales commissions, and other deal-specific underwriting fees. ${ }^{5}$

\section{A. Governing Law}

Eurobonds differ from domestic bonds in having a choice of law embedded within the contract, usually English or New York law (Tennekoon (1990, p. 161)). The 1939 U.S. Trustee Indenture Act seeks to protect the rights of individual bondholders by requiring unanimous agreement of bondholders prior to any renegotiation of the cash flows specified in the contract (Wood (1995, pp. 179-180)). In effect, private work-outs require unanimous agreement of bondholders. On the other hand, English law is more favourable for the timely and orderly renegotiation of contract terms as contracts generally only require a majority of the bondholders present at a valid meeting to approve the change. ${ }^{6}$

Also, because of professional liability concerns, trustees to issues under U.S. law often confine their activities to administrative duties associated with the issue (Tsatsaronis (1999, pp. 21-22)). In contrast, trustees in bonds issued under English law have greater scope to negotiate with the borrower to resolve the default. This is beneficial to Eurobond investors who prefer anonymity (reflected in the purchase of bearer bonds) and thus do not wish to reveal their identity in bankruptcy proceedings (see Smith and Walter (1997, p. 259)). The superiority of English law in the renegotiation of contract terms enhances the demand for Eurobonds issued under English law and reduces underwriter spreads.

To account for the influence of governing law, we create indicator variables for the two main governing laws and a miscellaneous category: 'NY_Law', 'English_Law' and

\footnotetext{
${ }^{5}$ Livingston and Miller (2000) use a similar definition of the underwriter spread.

${ }^{6}$ Tsatsaronis $(1999$, p. 23 ) notes that a quorum may range from $35 \%$ to $66 \%$ of the principal outstanding.
} 
'Misc_Law' respectively. Each takes the value of unity if the issue is subject to that governing law and zero otherwise. With the New York law omitted from the regression, we expect the coefficient of the English law variable to be negative while the sign of the coefficient of the miscellaneous laws variable is uncertain.

\section{B. Distribution Mechanism}

To avoid registration requirements of the U.S. Securities Act of 1933, U.S. Eurobond issuers must satisfy either the implied foreign offering exemption or the Rule 144A private placement exemption. With the former the issuer proclaims that the offer and sale of the Eurobonds is not registered with the SEC and that the bonds will not be offered or sold in the U.S. or to U.S. nationals for at least 90 days. On the other hand, the private placement exemption applies if there is no public offer and if the investor base is limited in number, "sophisticated", able to sustain losses, has purchased the bonds as principal, and has access to public information relating to the issuer (Bowe (1988, pp. 116-118)).

There is an important distinction in the use of the terms "private placement" and "public offering" between the Eurobond and U.S. domestic markets. For Eurobonds the term "private placement" refers to the distribution technique used to place the bonds, not a Rule 144A exemption as in U.S. markets. Thus a private placement of Eurobonds is "an offer of securities made to a limited number of investors or a single investor (and which are) generally not listed" (Fisher (1988, p. 222)). ${ }^{7}$ Moreover, a public offering of Eurobonds is defined by Fisher as "an offer of securities (normally listed) to the general public, usually through a selling group of international banks which market securities to their clients." There are two main listing centres for Eurobonds, the London and Luxembourg Exchanges. Each has extensive disclosure requirements for first time listings, including the lodging of preliminary and final prospectuses, annual reports, and associated

\footnotetext{
${ }^{7}$ However, some Eurobond private placements do have a Rule 144A exemption to assist in the marketing of the issue. Approximately $25 \%$ of the private placements in our sample have a Rule $144 \mathrm{~A}$ exemption.
} 
agreements (see Fisher (1988, pp. 105-110)). In contrast, a public issue in the U.S. signifies that the securities are registered under the U.S. Securities Act of 1933.

With Eurobond private placements confined to a relatively small investor base, and generally unlisted, the disclosure, distribution, and marketing costs are relatively small. Public offers generally require greater disclosure, a road show (dependent on size of the issue), and extra marketing effort. Moreover, a public offer may require a large underwriting syndicate resulting in greater costs for the lead underwriter in managing syndicate members (Chen and Ritter (2000)). These administrative and management costs are expected to add to the distribution costs of a public offer and increase underwriter fees.

The limited disclosure associated with private placements creates potential information asymmetries and contracting or agency problems between debt and equity holders. This may result in asset substitution as managers of firms with risky debt have an incentive to undertake more risky projects. Alternatively, firms with growth opportunities may underinvest in low risk, positive NPV projects. With greater disclosure, public issues involve less information asymmetries than private placements, reduced agency problems, lower risk, and thus lower underwriter spreads.

To capture the effect of choice of distribution mechanism on underwriter spreads we include an indicator variable, 'Public', which takes the value of unity for a public offer and zero otherwise. With the offsetting influences, the sign of its coefficient is uncertain.

\section{Certification and Signaling}

Underwriters provide certification and monitoring benefits to issuers by signaling the quality of the issue to the market. Chemmanur and Fulghieri (1994) argue that high reputation underwriters supply superior certification and monitoring services and provide credible signals to the market concerning the quality of the issue that low reputation 
underwriters are unable to replicate ${ }^{8}$. Similarly, Puri (1999) argues that high reputation underwriters incur greater costs in providing these services and hence charge higher fees.

Prior studies of underwriter spreads in U.S. debt and equity markets have used three approaches to proxy underwriter reputation: (i) Carter and Manaster (1990) use an integer ranking based on the underwriter's hierarchical bracket position in new issue tombstone announcements; (ii) Megginson and Weiss (1991) use the underwriter's market share (in dollar terms) over a prior period; and (iii) Roden and Bassler (1996) derive a proxy based on market opinion as determined in a survey but found it to be less useful than the other approaches. As Megginson and Weiss (1991, p. 890) find a high positive correlation between their market share proxy and that of Carter and Manaster's (1990) tombstone hierarchical bracket ranking, and a tombstone ranking of underwriters in the Eurobond market is not available, in this study we use the market share approach.

We define the variable 'UW_Mkt_Share' as the underwriter's market share of the Eurobond underwriting market (excluding equity linked issues) in the twelve months prior to the issue. ${ }^{9}$ A positive coefficient is expected for the variable, reflecting higher charges for the greater level of certification services provided by more reputable underwriters.

\section{Currency of Denomination}

Issuers are often drawn to the Eurobond market by the prospect of lower borrowing costs and select the currency of denomination on that basis. Currency swaps are then used to convert the exposure to a preferred currency. This arbitrage is facilitated by the choice of an underwriter who is able to efficiently manage and market the issue in that currency.

The suggestion that the choice of underwriter for Eurobond issues is driven more by the choice of currency denomination than the issuer's domicile is supported by the data in

\footnotetext{
${ }^{8}$ While the authors focus on the behaviour of underwriters in the equity market, they note that their model is also applicable to an asymmetrically informed debt market (Chemmanur and Fulghieri (1994, p58)).

${ }^{9}$ For multiple lead underwriters, the reputation variable takes the value of the highest market share of the lead underwriters.
} 
Table I (drawn from McCauley (1999)), which analyses 1996 issues of foreign bonds and Eurobonds where the underwriter was either German, French, English, Dutch, American or Japanese. For each nationality of the underwriter, issues are classified by currency and the nationality of the issuer. The table demonstrates that when the currency denomination is the underwriter's home currency, the underwriter is equally successful in competing for the underwriting business of foreign issuers as domestic issuers. On the other hand, when domestic issuers are borrowing in a foreign currency then home country underwriters are much less successful in competing for the business than if the issue were in the domestic currency. To illustrate from Table 1, for issues in the German mark, German lead underwriters obtained $44 \%$ of the business of German issuers and a comparable $37 \%$ of the business of foreign issuers. However when German issuers borrow in a foreign currency, German lead underwriters only obtained $16 \%$ of the business. This is strongly suggestive of underwriting in the Eurobond market being segmented by currency denomination.

\section{<Insert Table I About Here>}

Also, prior to the Euro, there was a strong investor preference for Eurobonds denominated in USD. ${ }^{10}$ Wood $(1995$, p. 6) attributes this to the role of the USD "as a reserve currency and the desire in Japan and Europe to maintain sovereignty over their own currencies, a desire expressed in exchange controls (Britain) and administrative guidelines (especially in Germany, Japan and Switzerland)." Furthermore, institutional investors are often restricted in their ability to invest in securities that are not denominated in their home currency. Lannoo (1998, p. 318) documents some of the important quantitative restrictions on pension fund investments in Europe, noting that German pension funds are prevented from investing more than $6 \%$ of their assets in non-EU bonds while over $80 \%$ of the

\footnotetext{
${ }^{10}$ Between 1980-2000, 36\% of all Eurobond issues were denominated in USD while 55\% of Eurobond issues by U.S. firms were in USD (see Claes et al (2002, p. 381-382)).
} 
portfolio must be currency matched. Hence currency preferences of institutional investors are influenced by the currency denomination of their liabilities.

Finally, domestic underwriters may benefit from better understanding movements in domestic interest and exchange rates and/or from superior access to investors wishing to invest in the domestic currency (see McCauley (1999, p. 6)). They may also be protected from competition from foreign domiciled underwriters by requirements that domestic banks be among the lead managers. ${ }^{11}$ These regulations force non-domestic underwriters to choose between establishing offshore subsidiaries, with increased costs of generating the marketing and research capability, or alternatively neglecting that sector of the Eurobond market.

We proxy currency denomination effects by a set of indicator variables for the three main currencies in our sample and a miscellaneous currency category: the U.S. dollar 'USD', German 'Mark', British 'Pound', and all other currencies 'Misc_Cur'. Each takes the value of unity if the Eurobond is denominated in that currency and zero otherwise. To avoid singularity, the 'USD' variable is excluded from the regression.

\section{E. Controls}

As controls we include proxies for investment horizon and credit risk, issue size, bond type, and a time trend. Longer maturity fixed rate bonds carry higher levels of risk as their future cash flows extend over longer time horizons. The greater the investment horizon risk the greater are the distribution costs and underwriter spreads for the issue (Livingston and Miller (2000) and Roden and Bassler (1996)). We proxy investment horizon risk by the natural log of the maturity of the Eurobond, 'LN_Maturity', and expect it to be positively related to underwriter spreads. ${ }^{12}$

\footnotetext{
${ }^{11}$ Lead managers of German mark denominated Eurobonds were required to be domiciled in Germany, but could be German subsidiaries of non-German banks (Fisher (1988, p. 134) and Bowe (1988, p. 17)).

${ }^{12}$ Using the natural log of maturity overcomes the skewness in the maturity variable.
} 
The credit risk proxy, 'Credit_Rating', takes the value of 15 for 'Aaa' rated bonds, 14 for 'Aa1', 13 for 'Aa2' and so on. Reflecting the higher distribution costs incurred by underwriters when placing higher-risk securities, we expect it to be inversely related to underwriter spreads. For issues that are not rated we include an indicator variable, denoted 'Not_Rated'. However, the sign of its coefficient is uncertain.

To preserve investor anonymity Eurobonds are generally issued in bearer form. They are transferable by delivery, and coupons and principal are payable to the bearer. As non-bearer bonds are less attractive investment vehicles to many Eurobond investors and require greater marketing effort, they are likely to involve higher underwriter spreads than bearer bonds. Hence, we include an indicator variable for non-bearer bonds, denoted 'Non_Bearer', and expect it to be directly related to underwriter spreads.

To proxy scale related influences on underwriter fees we include the log of issue size, 'LN_Size'. Reflecting economies of scale in underwriter fees for larger issues (see Altınkılıç and Hansen (2000)), we expect a negative relationship between issue size and underwriter spreads. Finally, we include a time trend variable, 'Time_Trend', that takes the value of 1 for issues launched in 1990, 2 for issues in 1991, and so on. A summary of the model is provided in Table II.

\section{<Insert Table II About Here>}

\section{DATA}

\section{A. Sample and Summary Statistics}

A sample of straight/fixed-rate Eurobonds issued by U.S. domiciled non-financial firms between January 1990 and December 1998 was drawn from the IFR Securities Omnibase Database. ${ }^{13}$ Limiting the sample to U.S. borrowers produces a relatively homogeneous sample of issuers, while the choice of sample period avoids the

\footnotetext{
${ }^{13}$ Financial firms are classified as firms with SIC classification code beginning with ' 6 '.
} 
complications of the introduction of the Euro in January $1999 .{ }^{14}$ Initially 611 issues met this criterion. In two multiple issue deals, an underwriter fee was only recorded for the largest issue. Rather than assume that the single recorded fee is representative of the fee in the remaining issues, we exclude these observations. A further 75 observations are excluded because of incomplete data relating to dependent or independent variables, resulting in a final sample of 534 Eurobonds issued by 61 U.S. non-financial firms.

Table III provides summary statistics for the sample. The mean underwriter spread is 145 basis points, with a median of 163 basis points, suggesting some skewness in the dependent variable. The mean issue size is US\$187m in constant 1995 dollars, and the average maturity is 5.2 years. Public offers account for $92 \%$ of the issues, while $80 \%$ are governed by New York law and $17 \%$ by English law. The most common currency of issue is the U.S. dollar with $43 \%$ of the issues denominated in USD, while $10 \%$ are denominated in the German mark and 8\% in Pound sterling. The Eurobonds are of high credit quality with $98 \%$ of the issues classified as investment grade, ${ }^{15} 1 \%$ below investment grade, and $1 \%$ 'Not-Rated'. In terms of Moody's ratings, 64\% are rated 'Aaa', 14\% 'Aa', 16\% 'A', $3 \%$ 'Baa', $0.2 \%$ 'Ba', and $1 \%$ ' $\mathrm{B}$ '. The average market share for lead underwriters in the sample is $4 \%$, with a range of 0 to $10 \%$.

\section{<Insert Table III About Here>}

The mean issue size of US\$187m is similar to the means of $\$ 162 \mathrm{~m}, \$ 178 \mathrm{~m}$ and $\$ 177 \mathrm{~m}$ in the U.S. studies of Jewell and Livingston (1998), Livingston and Miller (2000) and Roden and Mullineaux (2002) respectively. However, the mean underwriter spread of 145bps is higher than in U.S. studies where Jewell and Livingston (1998), Gande et al (1999), Livingston and Miller (2000) and Roden and Mullineaux (2002) report spreads of

\footnotetext{
${ }^{14}$ Over the 1990 to 1998 period U.S. issuers accounted for $11 \%$ of the total value of Eurobonds issued, second only to German issuers with $13.4 \%$ (IFR Database).

${ }^{15}$ Investment grade is defined as bonds rated Baa3 or higher by Moody's Investor Service.
} 
$125,132,111$ and $92 \mathrm{bps}$ respectively. ${ }^{16}$ Moreover, the mean maturity of 5.2 years is much less than in the Livingston and Miller (2000) and Roden and Mullineaux (2002) samples of 12.7 and 14.4 years, while the mean underwriter market share of $4 \%$ suggests a more competitive market than the 11\% mean market share in Roden and Mullineaux (2002). The Eurobonds are also higher credit quality with $1 \%$ below investment grade compared to $22 \%$ and 18\% in Jewell and Livingston (1998) and Roden and Mullineaux (2002) respectively.

\section{B. Clustering in the Underwriter Spread}

Recent studies have drawn attention to the high levels of clustering in U.S. IPO underwriter spreads at the 7\% level. Chen and Ritter (2000) explain this clustering by implicit or explicit collusion between underwriters to fix underwriter fees. However, Hansen (2001) finds no evidence of collusion in the market and concludes that the advent of the $7 \%$ contract is a competitive innovation of the firm commitment contract that best suits the initial public offering. While Hansen (2001) demonstrates sufficient competitive forces in the U.S. market to rule out collusion between underwriters, the advent of a single fee value (whether competitively or not competitively determined) poses significant econometric difficulties in estimation. Therefore, in Figure 1 we examine underwriter fees in our sample for evidence of clustering. An inspection of the Figure, which plots the underwriter spread against the natural log of issue size (in constant 1995 dollars), reveals little evidence of clustering of underwriter fees around any one value.

\section{<Insert Figure 1 About Here>}

We also calculate the Herfindahl Index to assess the concentration of underwriter fees at particular values. The Herfindahl Index is defined as:

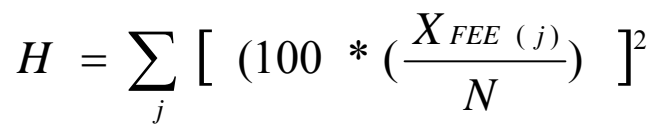

\footnotetext{
${ }^{16}$ Kim and Stulz (1988) also note that the underwriter spread on Eurobonds is larger than on domestic issues.
} 
where $X_{\mathrm{FEE}(\mathrm{j})}$ is the number of observations with $\mathrm{FEE}=\mathrm{FEE}(\mathrm{j})$ and $\mathrm{N}$ is the total number of observations. ${ }^{17}$ In interpreting the value of the Herfindahl index, populations are classified as 'un-concentrated' for values below 1000, moderately concentrated for values between 1000 and 1800, and highly concentrated for values greater than 1800 (see U.S. Department of Justice Web Site). The Herfindahl Index for the sample is 1256 suggesting a moderate level of concentration of underwriter fees. Thus unlike U.S. initial public offers, there is little evidence of clustering around a single value in Eurobond underwriter spreads. ${ }^{18}$

\section{RESULTS}

\section{A. Estimation Technique}

While Figure 1 reveals little evidence of clustering of underwriter spreads around a single value, it does suggest a bi-modal distribution with dominant frequencies in the 0$0.5 \%$ and $1.25-2 \%$ ranges. This reflects, at least in part, the dichotomous nature of key independent variables, i.e. the governing law, distribution mechanism, and currency choice variables. An inspection of ordinary least squares (OLS) residuals in preliminary estimates revealed that, while much of the bi-modality is "captured" by the dichotomous independent variables, the residuals exhibited evidence of non-normality using the Jarque-Bera test. ${ }^{19}$

With evidence of non-normal residuals, we use two alternative estimators. A standard approach is to bootstrap the standard errors of OLS estimates (Davison and Hinkley (1997, Ch. 6)). This involves drawing 2500 samples with replacement from OLS residuals and re-estimating the model to obtain bootstrapped coefficient standard errors. This has little effect on the standard errors, suggesting the non-normality is not serious.

The second approach involves constructing a new dependent variable, denoted

'Ordered_Fee', in which observed spreads are grouped into one of five categories:

\footnotetext{
${ }^{17}$ For this analysis each observed spread value in the data is viewed as a separate component of the "market".

18 The clustering of underwriter spreads around a single value appears to be a unique characteristic of IPOs as Chen and Ritter (2000) also noted little evidence of clustering in debt market underwriter spreads.

${ }^{19}$ A similar result is found when the dependent variable is transformed into the natural log form.
} 


$$
\begin{aligned}
& 0.0<{ }^{'} \mathrm{Fee}_{\mathrm{i}}{ }^{\prime}<0.5 \quad \text { 'Ordered_Fee' }=0 \\
& 0.5 \leq \text { 'Fee }_{\mathrm{i}}{ }^{\prime}<1.0 \quad \text { 'Ordered_Fee' }=1 \\
& 1.0 \leq \text { 'Fee }_{i}{ }^{\prime}<1.5 \quad \text { 'Ordered_Fee' }=2 \\
& 1.5 \leq{ }^{\prime} \mathrm{Fee}_{\mathrm{i}}{ }^{\prime}<2.0 \quad \text { 'Ordered_Fee' }=3 \\
& 2.0 \leq \text { 'Fee }_{\mathrm{i}}{ }^{\prime} \quad \text { 'Ordered_Fee' }=4
\end{aligned}
$$

The 'Ordered_Fee' variable provides an ordinal ranking of fees with an observation in the 'Ordered_Fee' $=2$ group ranked as having higher fees than those in the 'Ordered_Fee'=1 group. However, the value of the variable does not provide a measure of the relative size of the fees in one group vis-à-vis the other groups. While the ordinal ranking approach ignores potentially useful information relating to the size of fees both within and across groups, its advantage lies in its recognition of the grouping of observations as observed in Figure 1. Where the dependent variable is an ordinal ranking we estimate the model using the ordered probit technique (see Greene (1995, Ch. 23)). ${ }^{20}$

\section{B. OLS Bootstrapped Results}

OLS estimates with bootstrapped standard errors are reported in Table IV. ${ }^{21}$ Regs 1 and 2 utilize alternative proxies for underwriter reputation, with Reg 1 using the underwriter's market share, 'UW_Mkt_Share', while Reg 2 uses the underwriter's top 20 league table ranking, 'UW_League_Rank'. The top ranked underwriter for the year receives a reputation value of 20 , the second a value of 19 , and so on. Underwriters outside the top twenty receive a value of zero. Both variables are based on the dollar volume of all non-equity linked Eurobonds (for all nationalities of issuers) brought into the market. ${ }^{22}$ In Reg 3 'Credit_Rating' is replaced by 'Investment_Grade', an indicator variable for Eurobonds that are investment grade. The model fits the data reasonably well with an

\footnotetext{
${ }^{20}$ Ordered logit results were similar and hence are not reported.

${ }^{21}$ The model was also estimated with the dependent variable in log form but this had little effect on results.

${ }^{22}$ Where there are multiple lead underwriters the nominal dollar amount of the issue is split evenly between lead underwriters.
} 
adjusted $\mathrm{R}^{2}$ of 0.24 while the signs and significance of the estimated coefficients lend support to our a priori hypotheses relating to the determinants of the underwriter spread.

\section{<INSERT TABLE IV ABOUT HERE>}

\section{(i) Governing Law and Renegotiation}

The choice of governing law in the Eurobond market provides an opportunity to examine the effects of differential debt renegotiability across governing laws on underwriter spreads. Our results in Table IV show that underwriter spreads on issues governed by English law are some 15 bps lower than for otherwise similar issues governed by New York law. This is consistent with English law, and the activities of trustees under that law, being more flexible in handling situations of default compared to New York law. The ease of renegotiation lowers investment risk and underwriter spreads. The coefficient of the miscellaneous law indicator variable is also negative but not statistically significant.

\section{(ii) Distribution Mechanism}

Our results in Table IV are also consistent with the hypothesis that public offers of Eurobonds involve greater disclosure, issue and marketing costs, and thus higher underwriting fees, than privately placed Eurobonds. The coefficient on the 'Public' indicator variable is significant and positive suggesting that, ceteris paribus, underwriter fees on public offers are 65 bps higher than on private placements. This result contrasts with the U.S. bond market study of Livingston and Zhou (2002) where gross underwriter spreads on Rule 144A issues were found to be insignificantly different from those on public issues. Livingston and Zhou argue that there are offsetting influences of Rule 144A issues on underwriting fees with the effects of greater information asymmetries of private placements being offset by lower disclosure and marketing costs. In the Eurobond market, however, issuers of private placements are typically large and relatively transparent corporations with low risk and hence are unlikely to have significantly greater information 
asymmetries than issuers using public offers. Thus, the significant positive relationship between Eurobond underwriter spreads and the "Public" variable is not surprising.

\section{(iii) Certification and Signaling}

The regression results in Table IV are consistent with the theoretical analysis of Chemmanur and Fulghieri (1994) and Puri (1999) who suggest that high reputation underwriters provide additional services in the form of certification, signaling, and monitoring for the new issue, and therefore charge higher fees. In Reg 1 our proxy for underwriter reputation based on the underwriter's market share is positive and significant and suggests that underwriters, on average, increase the underwriting spread by 2 bps for each percent of market share. Noting that the maximum and minimum market shares in the sample are $10.5 \%$ and $0 \%$ respectively, this suggests a difference of 23 bps in the spreads charged by the most and least reputable underwriters. Similar results are found in Reg 2 where the underwriter market share variable is replaced by the underwriter's league table ranking. The coefficient is positive and statistically significant, with the most reputable underwriter charging 12 bps more than underwriters not ranked among the top 20 .

Our results for underwriter reputation differ from the U.S. results of Roden and Bassler (1996) and Livingston and Miller (2000) who find an inverse relationship between underwriter reputation and underwriter fees for municipal bonds and non-convertible debt. A possible explanation for the divergent results may lie in Eurobond issuers placing a greater value on the benefits of underwriter certification in the relatively unregulated, and more competitive Eurobond markets than issuers in U.S. domestic bond markets. It is noteworthy that Beatty and Welch (1996) find a positive relationship between underwriter reputation and spread in U.S. initial public equity offers which generally require greater certification and monitoring services than debt issues.

(iv) Currency of Denomination 
Regression coefficients of the currency choice indicator variables in Reg 1 are consistent with the hypothesis that currency choice influences Eurobond underwriter spreads. Between 1990 and 1998, underwriters charged significantly higher spreads for issues in currencies other than the USD. For 'Pound' and 'Misc_Cur' issues the spread was 18 to 19 bps higher than 'USD' issues while spreads on 'Mark' issues were 59 bps higher.

\section{(v) Controls}

Results for the investment horizon and credit risk variables in Reg 1 mirror those found in the U.S. bond market (see Livingston and Miller (2000) and Roden and Bassler (1996)). The statistically significant positive coefficient on the maturity variable is consistent with underwriters charging higher spreads for longer maturity issues bearing greater investment horizon risk, and implies that an increase in maturity from five to ten years increases the underwriter spread by 13 bps. Moreover, the significant negative coefficient on the 'Credit_Rating' variable is consistent with underwriters charging lower spreads for higher quality firms. Issues rated 'Baa3' carry underwriter spreads that are 21 bps higher than 'Aaa' rated issues. In Reg 3 the credit rating variable is replaced by an 'Investment_Grade' indicator variable. Relative to a below investment grade issue, the spread on an investment grade issue is 68 bps lower. ${ }^{23}$ Thus, Eurobond issues with greater risk have higher underwriter spreads.

We also find that Eurobonds issued in non-bearer form have significantly higher underwriter spreads (by 56 bps) than bearer bonds. This is consistent with bearer bonds being easier to market as they provide greater anonymity for investors, a feature valued by many Eurobond investors (see Wood (1995, p. 132)). The issue size variable has an insignificant positive coefficient in Regs 1 to 3 . Consistent with the U.S. debt market

\footnotetext{
${ }^{23}$ Livingston, Pratt and Mann (1995) find that underwriter fees are similar for investment grade bonds, but increase sharply for high-yield bonds. Also, Jewell and Livingston (1998) find that their 1980-1993 sample of domestic bonds have underwriter spreads that increase sharply for bonds below investment grade.
} 
studies of Livingston and Miller (2000) and Jewell and Livingston (1998), there is little evidence of scale economies in underwriter spreads of Eurobond issues by U.S. firms. ${ }^{24}$ Finally, the coefficient of the time trend variable is negative and significant at the $95 \%$ confidence level. Underwriter spreads have declined by some 25 bps over the sample period, possibly reflecting increased competition in the market.

\section{Alternative Estimators}

The Ordered Probit result corresponding to the specification of Reg 1 is reported as Reg 4 of Table IV. The model fits the data reasonably well, correctly predicting $54 \%$ of the observations of the ranked dependent variable. This compares with $20 \%$ for a naïve prediction that the observations are spread randomly across the five categories. The ordered probit results are generally consistent with the OLS bootstrapped results except that the coefficient of the underwriter reputation proxy, while retaining its positive sign, is no longer statistically significant. Thus our results are generally robust across the estimation techniques used to account for non-normality in the dependent variable.

A problem with our bootstrapped OLS results is the possibility of selection bias from the dichotomous distribution mechanism variable, 'Public'. ${ }^{25}$ The specification of the sample selection is known as the "treatment effects model" and applies when the indicator of the presence or otherwise of the sample selection is itself a determinant of underwriter spreads (Green (1995, pp.642-643) and Saunders and Srinivasan (2001)). As underwriter spreads are determined by the unobservable costs/benefits of the alternative distribution mechanisms, they are proxied by the observed indicator variable, 'Public'. If the observed choice of distribution mechanism is not randomly sampled from the population of the costs and benefits of the distribution mechanisms, then serious biases may result.

\footnotetext{
${ }^{24}$ Alternative functional forms of the scale variable were tried but all were statistically insignificant.

${ }^{25}$ While Livingston and Zhou (2002) note this possibility in regressions explaining U.S. bond yield spreads over Treasury, it is not treated in regressions explaining underwriter spreads.
} 
The solution to the selection problem is to use Heckman's (1979) two-stage maximum likelihood estimation technique. The first stage involves a probit model with the dichotomous 'Public' variable as the dependent variable and a set of independent variables reflecting the benefits/costs of choosing a public issue or a private placement. ${ }^{26}$ The estimate of the probability of a public issue from the first stage, the inverse Mills ratio or 'Lambda', replaces 'Public' in the second stage maximum likelihood estimation of the underwriter spread equation.

Our result using Heckman's estimator is reported as Reg 5 in Table IV. The coefficient of the inverse Mills ratio, Lambda, is positive and statistically significant consistent with public issues having higher disclosure and marketing costs than private placements. The coefficient of 'Lambda' is approximately half that of 'Public' in Reg 1. However, this need not imply a reduced sensitivity of underwriting spreads to the choice of distribution mechanism. The mean 'Lambda' of public issues is 0.131 compared to -1.422 for private placements. Taking the difference in means (1.553) and multiplying by the regression coefficient (0.352), Reg 5 suggests that underwriter spreads on public issues are 55 bps higher than private placements, a little less than the 65bps suggested by Reg 1.

The remaining coefficients in Reg 5 mirror those in Reg 1, although the credit rating variable is now only significant at the $90 \%$ confidence level while the issue size variable attains significance at the $95 \%$ level. The latter suggests the possibility of scale diseconomies, rather than scale economies, in underwriter spreads for large issues. ${ }^{27}$

\section{Analysis of the Currency Denomination Effects}

\footnotetext{
${ }^{26}$ The independent variables in the first stage probit model include underwriter reputation as proxied by UW_Mkt_Share, credit risk proxied by the indicator variables, Investment_Grade and Not_Rated, the natural logarithm of the size and maturity of the issue, LN_Maturity and LN_Size, indicator variables for issue characteristics of whether the Eurobonds are non-bearer or asset-backed, Non_Bearer and Asset_Backed, the number of Eurobond issues made by the issuer in the prior three year period, Number_Issues, and the Time_Trend variable. For space reasons the results of the first-stage regression are not reported.

${ }^{27} \mathrm{This}$ result may be spurious with large issues more likely to involve a public issue and thus associated with higher distribution costs.
} 
In Table $\mathrm{V}$ we examine several possible explanations for the currency denomination effects. Initially we consider the possibility that the higher underwriter spreads on nonUSD denominated issues may reflect the presence of a currency swap in the financing arrangement. As noted previously, one of the driving forces underlying the development of the Eurobond market has been the currency swap market. High quality U.S. firms may take advantage of arbitrage opportunities to reduce borrowing costs by denominating Eurobond issues in a foreign currency and using the swap market to convert the exposure back to USDs. Thus a component of the higher underwriter spreads on some non-USD issues could be the additional costs incurred by the underwriter in arranging the currency swap.

\section{<Insert Table IV About Here>}

The currency swap indicator variable, 'C_Swap', takes the value of unity if the IFR database records a currency swap associated with the Eurobond and zero otherwise. In our sample only $15.4 \%$ of the issues have a currency swap. ${ }^{28}$ Not surprisingly, they are more frequently observed in non-USD denominated issues $(25.2 \%)$ than USD issues $(2.2 \%)$. In Reg 1 the coefficient of the currency swap variable is insignificant suggesting that, where currency swaps are associated with the Eurobond issue, underwriters do not incorporate an additional charge in the underwriter spread for arranging the swap. ${ }^{29}$

A second possibility is that currency denomination effects are related to the importance of the currency within the Eurobond market. If the market in a particular currency of denomination is limited, underwriters will need to expend greater marketing effort to place issues in that currency. Moreover, thin currency segments of the market are less likely to be able to support a broad range of underwriters, allowing underwriters to

\footnotetext{
${ }^{28}$ Where an issue makes no reference to the presence of a currency swap a zero value (no swap) is assumed. However, no mention of a swap is consistent with either of two possibilities: (i) there was no swap associated with the issue; or (ii) there was a swap but it was not disclosed. Hence the 'C_Swap' variable may contain considerable measurement error.

${ }^{29}$ The 'C_Swap' variable was also introduced interactively with the currency denomination indicator variables but it was also statistically insignificant in this form.
} 
charge higher spreads in those currencies. To examine this possibility we construct a variable, 'Cur_Volume', which is the ratio over the 1990-1998 period of the value of all non-equity linked Eurobond issues in the currency of denomination of the issue to the value of USD issues. It captures the relative importance of the currency of issue in the Eurobond market over the sample period, taking the value of unity for USD issues and approaching zero for currencies that play little role in the market. We expect the currency volume variable to be inversely related to the underwriter spread.

In Reg 2 of Table $\mathrm{V}$ the currency volume variable, which replaces the currency indicator variables, has the predicted negative sign and is highly significant. This is consistent with the currency denomination effects in the Eurobond underwriting market being related to the relative importance of currencies in the market. Moreover, with the 'Mark' and 'Pound' market volumes being 40\% and 32\% of 'USD' volumes respectively, the regression coefficients suggest that underwriter spreads on 'Mark' and 'Pound' denominated issues are 16 and 19 bps higher than similar USD issues. Relative to the results in Table IV, the currency volume variable produces a similar result for 'Pound' issues but underestimates the premium charged by underwriters for 'Mark' issues.

A third possibility is that the currency effects may be related to the degree of competition among underwriters within currencies. This is explored in Reg 3 where we include a measure of the concentration of lead underwriters within the currency of the issue. 'LN_UW_Herfindahl', is the natural $\log$ of the Herfindahl index ${ }^{30}$ of underwriter concentration based on the value of non-equity linked Eurobonds in the currency during the 1990-1998 period. ${ }^{31}$ A positive coefficient is expected with higher underwriter spreads in

\footnotetext{
${ }^{30}$ To account for subsidiaries, the index is based on ultimate parents of the underwriters. Where there are multiple lead underwriters, the transaction amount is spread evenly between the underwriters.

${ }^{31}$ Interestingly, the currency volume and the currency underwriter concentration variables are highly negatively correlated $(\rho=-0.79)$. High underwriter concentration in a currency is associated with relatively low volume of issuance in that currency.
} 
currencies where underwriting is more concentrated. While the regression coefficient for this variable in Reg 3 has the expected positive sign, it is only significant at the $90 \%$ confidence level. Consequently there is weak support for the hypothesis that the currency effects reflect differences in competition among underwriters across currencies.

\section{SUMMARY}

Our primary contribution has been to provide an empirical analysis of the pricing of underwriter services in the Eurobond market. Although there is an extensive empirical literature on the determinants of underwriter spreads in U.S. bond markets, our study is unique in its focus on the Eurobond market. Moreover, we examine how two unique features of Eurobonds, the choice of governing law and currency of denomination, affect underwriter spreads. In addition, we examine the effects of the choice of distribution mechanism and underwriter reputation on underwriter spreads where U.S. studies have found conflicting results.

Using a relatively homogeneous sample of straight/fixed rate Eurobond issues of U.S. non-financial firms over the 1990-1998 period and several estimation techniques to account for non-normality of regression residuals and potential selection bias, there are four main findings which are robust across the alternative regression treatments. First, if the Eurobond is governed by English law the underwriter spread is significantly less than if governed by New York law. Relative to New York law, English law is more favourable for the timely and orderly renegotiation of contract terms as English law contracts generally only require a majority of the bondholders present at a valid meeting to approve the change. Moreover, trustees in bonds issued under English law have greater scope to negotiate with the borrower to resolve the default. Hence our result is consistent with the superiority of English law in the renegotiation of contract terms lowering investment risk and underwriter spreads. 
Second, the choice of distribution mechanism has a significant influence on the underwriter spread, with direct placements having smaller spreads than public offers. This is consistent with Shapiro's (1999, p. 534) suggestion that private placements of Eurobonds are simpler, easier to expedite, and provide a greater degree of anonymity for the investor than public offers. Our result contrasts with that of Livingston and Zhou (2002) who find no significant difference between underwriter spreads on public issues and private placements in U.S. bond markets and argue that the effects of greater information asymmetries of private placements are offset by lower disclosure and marketing costs. As issuers of private placements in the Eurobond market are typically large, relatively transparent corporations with low risk, our result is consistent with information asymmetries being of lesser concern in the Eurobond market.

Third, in contrast with the U.S. bond market studies of Roden and Bassler (1996) and Livingston and Miller (2000), who find an inverse relationship between underwriter reputation and underwriter fees, we find a didect relationship with higher reputation underwriters charging higher fees. Moreover, the direct relationship is consistent with the theoretical analysis of Chemmanur and Fulghieri (1994) and Puri (1999) and suggests thatissuers may place a greater value on the benefits of underwriter certification in the relatively unregulated, and more competitive, Eurobond markets than issuers in U.S. domestic bond markets.

Finally, Eurobonds that are denominated in currencies other than the USD have significantly higher underwriter spreads than those denominated in USD. Moreover, underwriter spreads are significantly higher for issues in currencies that are relatively less important in terms of issue volumes and for currencies where underwriting activities are more concentrated. 
The results are not only statistically significant but are also economically significant. For example, the underwriting fee on the average size Eurobond governed by UK law is US\$286,000 less than if it were governed by New York Law, while a public issue generates US\$1.21m more in underwriting fees than if it were privately placed. It will also incur US\$1.08m more in underwriting fees if it is denominated in German Marks, and US\$342,000 more if it is denominated in U.K. Pounds, than if denominated in USD.

There are several possible extensions of the study. The finding that the choice of governing law, distribution technique, and currency of denomination play a prominent role in determining underwriting fees suggests the need for a group of studies focusing on the determinants of these decisions within the Eurobond market. Moreover, the introduction of the Euro in January 1999 raises an interesting question of its influence on underwriter spreads. The Euro has reduced currency segmentation within the international bond market by forming a common currency for member countries and allowing institutional investors from member countries to invest in Euro denominated bonds rather than the legacy home currency. By broadening the market to encompass a broader spectrum of investors and underwriters with the relevant expertise, underwriter spreads are likely to have declined relative to those observed prior to the Euro (see McCauley (1999, pp.5-6)). 


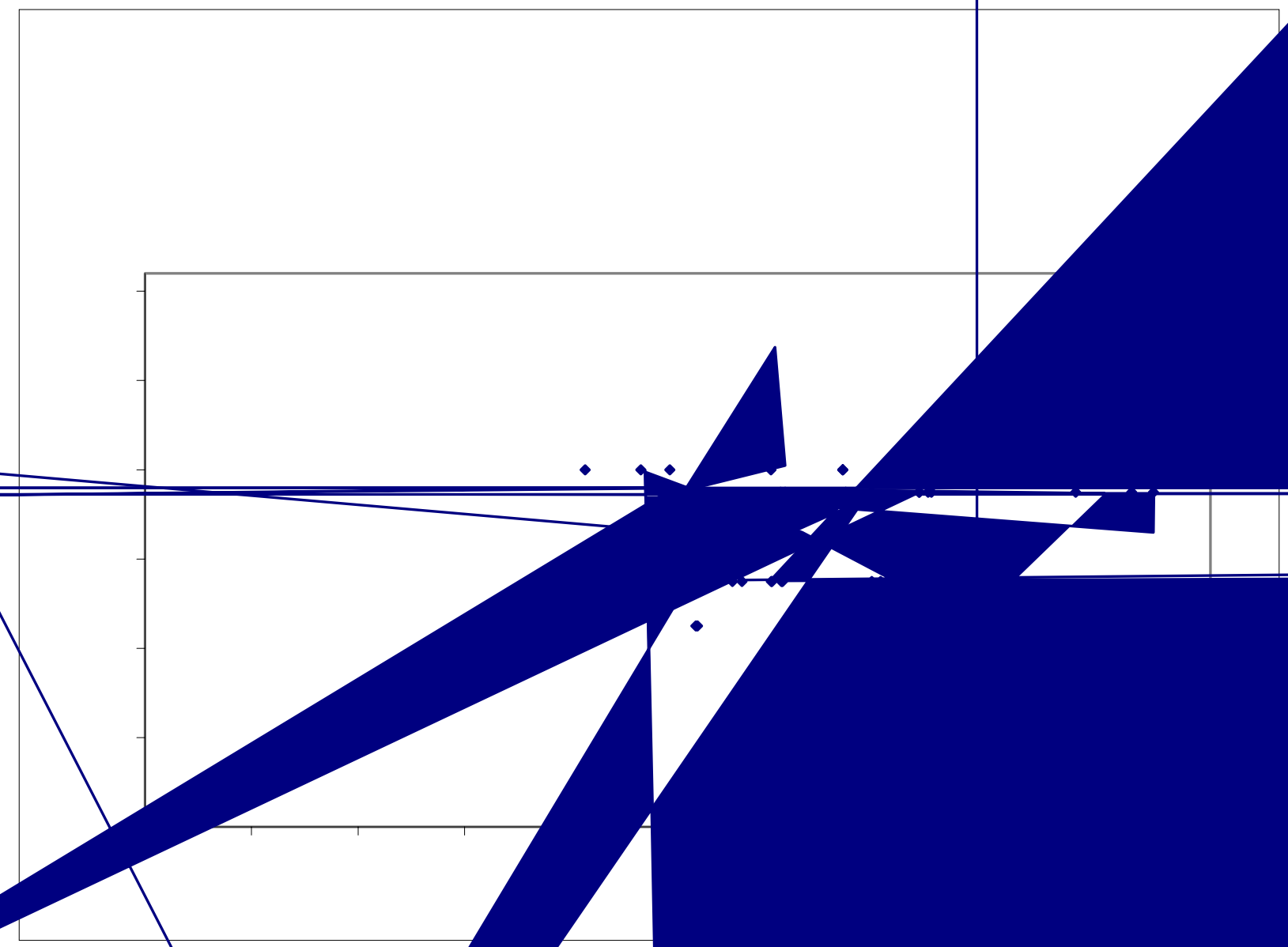




\section{TABLE I \\ CURRENCY AND HOME-COUNTRY RELATIONSHIP IN THE CHOICE OF UNDERWRITER, 1996}

Data includes all international bonds in the Euromoney database, including bonds issued under mediumterm note programmes, that are not equity-related. Total amount of bond issuance by currency: German Mark: \$81bn; French Franc: \$37bn, English Pound: \$54bn; Dutch Guilder: \$22bn; U.S. Dollar: \$319bn; Japanese Yen: $\$ 91 \mathrm{bn}$; Total: $\$ 725 \mathrm{bn}$. The figures represent the percentage of issues underwritten by German, French, English, Dutch, U.S. and Japanese Underwriters segmented by currency of issue and issuer nationality. The underwriter's market share (\%) denotes the proportion of bonds underwritten by underwriters of nationality ' $\mathrm{N}$ ', that are issued by issuers of nationality $\mathrm{N}$ (and Non-nationality ' $\mathrm{N}$ ') and denominated in currency N (and Non-nationality ' $\mathrm{N}$ '). For example, when issues are in the German mark, German lead underwriters obtained $44 \%$ of the business of German issuers and $37 \%$ of the business of foreign issuers. However when German issuers $b$ 
TABLE II

SUMMARY OF THE MODEL

A summary of the model and expected relationships with the dependent variable, 'Fee'.

\begin{tabular}{|l|l|l|}
\hline Variables & Name & $\begin{array}{l}\text { Expected Sign of the } \\
\text { Regression Estimate }\end{array}$ \\
\hline DISTRIBUTION METHOD & English_Law & -ve \\
CERTIFICATION AND SIGNALING & Misc_Law & Uncertain \\
CURRENCY EFFECTS & Public & Uncertain \\
& UW_Mkt_Share & +ve \\
CONTROLS & Pound & Uncertain \\
INVESTMENT HORIZON RISK & Mark & Uncertain \\
CREDIT RISK & Misc_Cur & Uncertain \\
& & \\
SCALE EFFECTS & LN_Maturity & +ve \\
NON-BEARER BONDS & Credit_Rating & -ve \\
TIMETREND & Not_Rated & Uncertain \\
& LN_Size & -ve \\
\hline
\end{tabular}




\section{TABLE III \\ SUMMARY STATISTICS}

Summary statistics are reported for the sample of 534 straight/fixed rate Eurobonds issued by U.S. non-financial firms between 1990 and 1998. The dependent variable, 'Fee', is the gross underwriter spread in percentage form.

\begin{tabular}{|lccccc|}
\hline & \multicolumn{5}{|c|}{ Descriptive Statistics } \\
\cline { 2 - 6 } & Mean & Std. Dev & Median & Min & Max \\
\hline DEPENDENT VARIABLE & & & & & \\
Fee (\%) & 1.45 & 0.59 & 1.63 & 0.10 & 3.00 \\
GOVERNING_LAW & & & & & \\
NY_Law & 0.80 & 0.40 & 1.00 & 0.00 & 1.00 \\
English_Law & 0.17 & 0.37 & 0.00 & 0.00 & 1.00 \\
Misc_aaw & 0.03 & 0.17 & 0.00 & 0.00 & 1.00 \\
IISTRIBUTIONMECHANISM & & & & & \\
Public & 0.92 & 0.28 & 1.00 & 0.00 & 1.00 \\
& & & & & \\
CERTIFICATIONANDSIGNALING & & & & & \\
UW_Mkt_Share & 0.04 & 0.03 & 0.04 & 0.00 & 0.10 \\
CURRENCY EFFECTS & & & & & \\
USD & & & & & \\
Pound & 0.43 & 0.50 & 0.00 & 0.00 & 1.00 \\
Mark & 0.08 & 0.28 & 0.00 & 0.00 & 1.00 \\
Misc_Cur & 0.10 & 0.30 & 0.00 & 0.00 & 1.00 \\
CONTROLS & 0.39 & 0.49 & 0.00 & 0.00 & 1.00 \\
LN_Maturity & & & & & \\
Credit_Rating & & & & & \\
Not_Rated & 1.47 & 0.55 & 1.58 & 0.00 & 3.69 \\
LN_Size & 13.36 & 2.94 & 15.00 & 0.00 & 15.00 \\
Non_Bearer & 0.01 & 2.94 & 0.00 & 0.00 & 1.00 \\
Time_Trend & 5.00 & 0.73 & 5.10 & 2.23 & 6.73 \\
& 0.02 & 0.13 & 0.00 & 0.00 & 1.00 \\
& 6.31 & 2.20 & 7.00 & 1.00 & 9.00 \\
\hline
\end{tabular}


TABLE IV

EUROBOND UNDERWRITER SPREAD REGRESSION RESUlTS 


\section{TABLE V}

\section{EUROBOND UNDERWRITER SPREAD REGRESSION RESULTS: ANALYSIS OF THE CURRENCY EFFECTS}

The regressions are estimated using Ordinary Least Squares and Bootstrapped standard errors with 2500 samples drawn with replacement from the regression residuals. The dependent variable is 'Fee'.

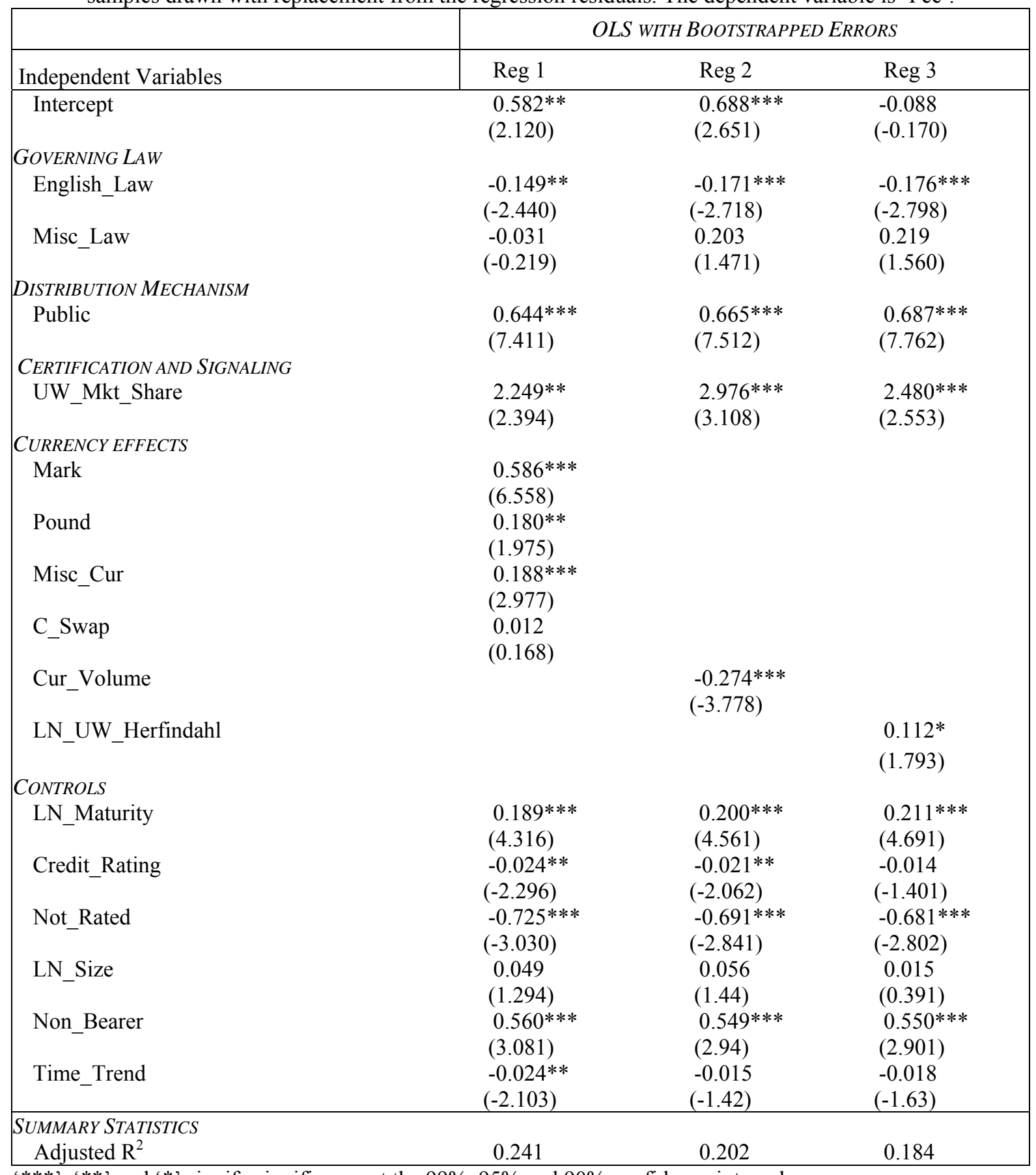

‘***’, ‘**' and '*’' signify significance at the $99 \%, 95 \%$ and $90 \%$ confidence intervals. 


\section{BIBLIOGRAPHY}

Altınkılıç O. and R. Hansen (2000), 'Are there economies of scale in underwriting fees? Evidence of rising external financing costs.', Review of Financial Studies, Vol. 13(1), pp. 191-218.

Beatty, R.P. and I. Welch (1996), 'Issuer expenses and legal liability in initial public offerings', Journal of Law and Economics, Vol. 39(2), pp. 545-602.

Bowe, M. (ed.) (1988), Eurobonds (Square Mile Books, Dow Jones-Irwin, Homewood, Ill).

Carey, M., S. Prowse, J. Rea and G. Udell (1993), 'The Economics of the Private Placement Market.' Board of Governors of the Federal Reserve System, Washington.

Carter, R. and S. Manaster (1990), 'Initial public offerings and underwriter reputation.', Journal of Finance, Vol. 45, pp. 1045-1068.

Chemmanur, T. and P Fulghieri (1994), 'Investment bank reputation, information production, and financial intermediation.' The Journal of Finance, Vol. 54, pp. 57-76.

Chen, H. and J. R. Ritter (2000), 'The seven percent solution.', Journal of Finance, Vol. 55(3), pp. 1105-1131.

Claes, A., M.J.K. De Ceuster and R. Polfiet (2002), 'Anatomy of the eurobond market.', European Financial Management, Vol. 8(3), pp. 373-386.

Davison, A.C. and D.V. Hinkley (ed.) (1997) 'Bootstrap Methods and their Application.' Cambridge University Press, Cambridge, UK.

Fisher, F.G. (ed.) (1988), Eurobonds, Euromoney Publications PLC, London.

Gande, A., M. Puri and A. Saunders (1999), 'Bank entry, competition and the market for corporate securities underwriting.' Journal of Financial Economics, Vol. 54(2), pp. 165-195.

Giddy, I. (ed.) (1995), Global Financial Markets., Lexington Book Press, Mass, D.C.

Greene, W.H., (ed.) (1995), Limdep Version 7.0. Econometric Software Inc., Bellport, NY.

Hansen, R. (2001), 'Investment banks compete in IPOs? The advent of the "7\% plus contract"., Journal of Financial Economics, Vol. 59(3), pp. 313-346.

Heckman, J.J. (1979), 'Sample selection bias as a specification error.' Econometrica, Vol. 47, pp. 153-161.

Jain, B. and O. Kini (1999), 'On investment banker monitoring in the new issue market.' Journal of Banking and Finance, Vol. 23(1), pp. 49-84.

Jewell, J. and M. Livingston (1998), 'Split ratings, bond yields, and underwriter spreads.', The Journal of Financial Research, Vol. 21(2), pp. 185-204. 
Kim, Y. C. and R. M. Stulz (1988), 'The Eurobond Market and corporate financial policy.', The Journal of Financial Economics, Vol. 22, pp. 189-205.

Lanoo, K. (1998) 'Institutional investors, capital markets and EMU.', in Blommestein, H., Funke, N., (Eds.), OECD, Paris, pp. 315-331.

Livingston, M. and R. Miller (2000), 'Investment bank reputation and the underwriting of non-convertible debt.', Financial Management, Vol. 29(2), pp. 21-34.

Livingston, M., H. Pratt and C. Mann (1995), 'Drexel, Burnham, Lambert's debt issues.', Journal of Fixed Income, Vol. 4, pp. 58-75.

Livingston, M. and L. Zhou (2002), 'The impact of rule 144A debt offerings upon bond yields and underwriter fees.' Financial Management, Vol. 31(4), pp. 5-27.

McCauley, R.N. (1999), 'The Euro and the Liquidity of European Fixed Income Markets.', in Bank for International Settlements, CGFS Publications, Basle, www.bis.org/publ.

Megginson, W. and K. Weiss (1991), 'Venture capitalist certification in initial public offerings.' Journal of Finance, Vol 46, pp. 879-904.

Puri, M., 1999, 'Commercial banks as underwriters: Implications for the going public process.', Journal of Financial Economics, Vol. 54(2), pp. 133-163.

Roden, P. and J. Bassler (1996), 'Effect of underwriter prestige on the interest cost of municipal bond offerings.', The Financial Review, Vol. 31(3), pp. 641-666.

Roden, P. and D. Mullineaux (2002), 'Debt underwriting by commercial bank-affiliated firms and investment banks: more evidence.' The Journal of Banking and Finance, Vol. 26, pp. 689-718.

Saunders, A. and A. Srinivasan (2001), 'Investment banking relationships and merger fees.', Working Paper (Stern School of Business, NYU).

Schnabel, J. and E. Roumi (1994) 'Risk incentive problems and foreign currency bonds.', Journal of Economics and Business, Vol. 12(2), pp.167-177.

Smith, R.C. and I. Walter (ed.) (1997), Global Banking. Oxford University Press, NY.

Tennekoon, R. (ed.) (1990), The Law and Regulation of International Finance. Butterworth Legal Publishers, London : Austin, Texas.

Tsatsaronis, K. (1999), 'The effect of collective action clauses on sovereign bond spreads.' BIS Quarterly Review, (Nov 1999), pp. 22-23.

Wood, P.R. (1995), International Loans, Bonds, and Securities Regulation. Sweet and Maxwell Limited, London. 